\title{
Implementasi manajemen akreditasi perpustakaan perguruan tinggi berstandar nasional di Universitas Negeri Malang
}

\author{
Teguh Yudi Cahyono1, Umi Masruroh², Sarwono ${ }^{3}$ \\ ${ }^{1}$ Magister Manajemen Pendidikan Tinggi, Universitas Brawijaya \\ Jl. M.T. Haryono No.163, Ketawanggede, Malang, Jawa Timur, 65145 \\ 2Politeknik Negeri Malang \\ Jl. Soekarno Hatta No.9, Lowokwaru, Malang, Jawa Timur, 65141 \\ ${ }^{3}$ Fakultas Ilmu Administrasi, Universitas Brawijaya \\ Jl. M.T. Haryono No.163, Ketawanggede, Malang, Jawa Timur, 65145 \\ E-mail: ${ }^{1}$ teguhmmpt2019@student.ub.ac.id, ${ }^{2}$ umi.masruroh@polinema.ac.id, ${ }^{3}$ sarwono@ub.ac.id
}

Received: July 2020; Accepted: April 2021; Published: June 2021

\begin{abstract}
University library accreditation aims to improve library quality. In order to get formal recognition from the state, university libraries apply for accreditation to the National Library to assess whether they have met national standards. This study aimed to determine implementation the management of university library accreditation with national standards at the University of Malang (UM). The research method used the descriptive qualitative method, which described management functions performed by UM library in the university library accreditation. The results research showed that library accreditation management carries out planning, organizing, implementing, and monitoring processes. Management functions are described in accreditation ranging from planning to supervisory functions. The planning process is to design accreditation activities structurally and organizationally to achieve the expected conditions through team planning, physical evidence, and accreditation performance. Organizing processes are forming an organizational structure and detailing the duties of accreditation team members to play an effective role by classifying accreditation instruments, organizing teamwork, and accreditation documents. General and technical guidelines for university library accreditation guide the implementation process to obtain optimal performance from the accreditation team through completing documents, preparing for visitations, correcting forms, and conducting self-assessments. The monitoring process avoids deviations by evaluating the administration, budget, forms, performance, and physical evidence of accreditation. The study concludes that the implementation of accreditation management through planning, organizing, implementing, and monitoring aims that the UM library can achieve accreditation objectives, namely obtaining satisfactory results as well as the legitimacy, reputation, and legality of the library.
\end{abstract}

Keywords: Management; Accreditation; National standard of the library; University library

\begin{abstract}
Abstrak
Akreditasi perpustakaan perguruan tinggi bertujuan meningkatkan kualitas perpustakaan. Untuk mendapatkan pengakuan formal dari negara, perpustakaan perguruan tinggi mengajukan akreditasi kepada perpustakaan nasional untuk dinilai apakah telah memenuhi standar nasional. Penelitian ini bertujuan untuk mengetahui bagaimana implementasi manajemen akreditasi perpustakaan perguruan tinggi berstandar nasional di Universitas Negeri Malang (UM) melalui proses perencanaan, pengorganisasian, pelaksanaan, dan pengawasan. Metode penelitian yang digunakan metode kualitatif deskriptif, yang menggambarkan fungsi manajemen yang dilakukan Perpustakaan UM dalam akreditasi perpustakaan perguruan tinggi. Hasil penelitian menunjukkan bahwa manajemen akreditasi perpustakaan yang dilakukan terdiri dari proses perencanaan, pengorganisasian, pelaksanaan, dan pengawasan. Fungsi manajemen dideskripsikan dalam akreditasi mulai fungsi perencanaan hingga pengawasan. Proses perencanaan yaitu dengan merancang kegiatan akreditasi secara struktural dan organisasional untuk mewujudkan kondisi yang diharapkan melalui perencanaan tim, bukti fisik, dan kinerja akreditasi. Proses pengorganisasian yaitu membentuk struktur organisasi serta merinci tugas anggota tim akreditasi sehingga dapat berperan dengan baik dengan mengelompokkan instrumen akreditasi, mengorganisasi kerja tim, dan dokumen akreditasi. Proses pelaksanaan berpedoman pada petunjuk umum dan teknis akreditasi perpustakaan perguruan tinggi agar didapatkan kinerja optimal dari tim akreditasi melalui pemenuhan dokumen, mempersiapkan visitasi, mengoreksi borang, dan melakukan self assesment. Proses pengawasan menghindari penyimpangan dengan mengevaluasi administrasi, anggaran, borang, kinerja, dan bukti fisik akreditasi. Simpulan penelitian ialah implementasi manajemen akreditasi yang dilakukan melalui perencanaan, pengorganisasian, pelaksanaan dan pengawasan bertujuan agar perpustakaan UM dapat mencapai tujuan akreditasi yaitu memperoleh hasil yang memuaskan disertai legitimasi, reputasi, dan legalitas perpustakaan.
\end{abstract}

Kata Kunci: Manajemen; Akreditasi, Standar nasional perpustakaan, Perpustakaan perguruan tinggi 


\section{PENDAHULUAN}

Beberapa perpustakaan perguruan tinggi di Indonesia telah memiliki dukungan rektor atau pimpinan lembaga, memiliki sumber daya manusia yang berkualitas, dan mendapatkan dukungan anggaran besar untuk berkembang secara pesat. Di sisi lain, banyak juga perpustakaan perguruan tinggi yang masih kekurangan koleksi, mempunyai Sumber Daya Manusia (SDM) yang rendah, manajemen dan layanan yang masih belum memanfaatkan kecanggihan teknologi informasi dan komunikasi. Berdasarkan data statistik Perpustakaan Nasional Republik Indonesia (2015), Perpustakaan perguruan tinggi yang terdaftar di perpustakaan nasional berjumlah 2.428 unit. Keseimbangan kuantitas dan kualitas penyelenggaraan perpustakaan perguruan tinggi tetap fokus utama meski jumlah perpustakaan perguruan tinggi yang terdaftar terus bertambah. Hal ini ditambah perubahan bahwa perpustakaan yang mendapatkan akreditasi A terbanyak berasal dari jenis perpustakaan perguruan tinggi.

Oleh karena itu, perpustakaan perguruan tinggi dapat dijadikan sebagai role model dalam membina perpustakaan secara nasional. Perpustakaan Nasional Republik Indonesia (2015) menambahkan bahwa pada data akreditasi nasional 2016, 40 perpustakaan perguruan tinggi sudah memperoleh akreditasi A, 49 perpustakaan perguruan tinggi memperoleh $\mathrm{B}$, dan 31 perpustakaan memperoleh akreditasi C. Sesuai data 2.428 perpustakaan perguruan tinggi yang terdaftar, baru sekitar 5\% (120 perpustakaan) yang telah melaksanakan akreditasi. Perpustakaan perguruan tinggi masih banyak yang belum memiliki akreditasi. Padahal, akreditasi dapat memberikan jaminan perpustakaan perguruan tinggi untuk memenuhi standar mutu yang ditetapkan. Selain itu, perpustakaan yang telah memiliki akreditasi dapat memberikan pelayanan perpustakaan yang berkualitas untuk pemustaka.

Adapun lembaga perpustakaan yang sudah maju dapat dilihat dari kualitas lembaga perpustakaan yang bersangkutan. Indikator perpustakaan yang berkualitas, di antaranya memiliki tujuan dan strategi organisasi yang baik, melakukan evaluasi rutin dan bertahap melalui identifikasi, mempertimbangkan dan mengukur variabel penting, memiliki konsep kerangka kerja lengkap dan baik meliputi komponen terkait sistem perpustakaan, dan dapat mengelola perubahan yang ada (Asmosatunah, 2018). Pemerintah sendiri untuk memfasilitasi akreditasi perpustakaan telah mengeluarkan berbagai kebijakan terkait akreditasi perpustakaan perguruan tinggi, di lembaga pemerintah atau instansi swasta, di antaranya Peraturan Pemerintah Republik Indonesia, Undang-Undang tentang perpustakaan, dan Peraturan Perpustakaan Nasional Republik Indonesia Nomor 10 Tahun 2018 Tentang Instrumen Akreditasi Perpustakaan Perguruan Tinggi. Akreditasi dijelaskan sebagai berikut.

“Akreditasi dilakukan untuk menilai tingkat kesesuaian pelaksanaan standar nasional perpustakaan, instrumen akreditasi perpustakaan perguruan tinggi disusun untuk proses kegiatan akreditasi, dan perpusnas-lah yang menetapkan Instrumen Akreditasi Perpustakaan Perguruan Tinggi" (Peraturan Perpustakaan Nasional Nomor 10 Tahun 2018 Tentang Instrumen 
Akreditasi Perpustakaan Perguruan Tinggi, 2018).

Dengan demikian, setiap perpustakaan yang mengajukan akreditasi harus merencanakan, mengorganisasikan, melaksanakan, mengevaluasi, dan mengoptimalkan sumber daya yang dimilikinya. Berlakunya kebijakan akreditasi tersebut, Perpustakaan Universitas Negeri Malang (UM) berupaya mengimplementasikan dalam setiap penyelenggaraan pelayanan perpustakaan. Maka, kebijakan akreditasi perpustakaan perlu dilaksanakan dan permasalahan yang menghambat akreditasi harus dicari solusinya. Implementasi kebijakan sendiri adalah kegiatan melaksanakan kebijakan akreditasi, yang sudah diselenggarakan perpustakaan nasional menggunakan beberapa indikator dalam mewujudkan sasaran kebijakan (Aray, Lumolos, \& Sampe, 2019).

Perpustakaan Universitas Negeri Malang membutuhkan Sumber Daya Manusia yang handal untuk mengimplementasikan kebijakan akreditasi. Hal ini melalui pembangunan kerja tim yang solid yang dapat digunakan perpustakaan saat melaksanakan rangkaian proses akreditasi (Fatmawati, 2016). Sumber Daya Manusia perpustakaan dapat saling membantu dalam menyelesaikan akreditasi agar borang dapat terselesaikan dan mendapatkan nilai akreditasi yang baik. Beberapa hubungan kerja sama yang menyenangkan dapat menimbulkan perasaan yang menyenangkan di antara anggota dalam tim kerja.

Manajemen perpustakaan merupakan kegiatan mencapai tujuan perpustakaan dengan memanfaatkan sumber daya yang dimiliki, dengan menjalankan tugas, fungsi, dan disiplin ilmu manajemen
(Lasa, 2017). Perpustakaan dalam mencapai tujuan tersebut hanya dapat dicapai melalui Sumber Daya Manusia dan non Sumber Daya Manusia, seperti anggaran, sarana dan prasarana, kebijakan, dan teknologi informasi. Berbagai sumber daya perpustakaan harus dikelola melalui aktivitas manajemen yang bagus, di antaranya proses merencanakan, mengorganisasikan, memilih kepala perpustakaan, pemonitoran, dan evaluasi yang mampu menghasilkan pelayanan perpustakaan yang berkualitas.

Pada perpustakaan perguruan tinggi, manajemen perpustakaan perguruan tinggi erat kaitannya dengan konsep manajemen itu sendiri. Perpustakaan perguruan tinggi dalam mencapai tujuan yang ingin dicapai akan menggunakan manajemen, yang berarti, "Mengatur dan membuat sesuai keinginan organisasi dengan mengoptimalkan sumber daya yang dimiliki (Nurohman, 2016). Manajemen yang bagus akan mudah mencapai tujuan perpustakaan, seperti tujuan pegawai dan tujuan dari pihak yang berkepentingan. Maka, untuk mencapai suatu tujuan, dibutuhkan ilmu dan seni dari manajemen dalam mengelola proses optimalisasi berbagai sumber daya yang dimiliki organisasi melalui keefektifan dan efisien (Samsuni, 2017).

Manajemen perpustakaan perguruan tinggi merupakan bidang kajian dan praktik terkait organisasi perpustakaan di perguruan tinggi. Manajemen perpustakaan perguruan tinggi merupakan proses manajemen dalam pelaksanaan tugas dalam mengelola perpustakaan perguruan tinggi melalui pengoptimalan sumber daya perpustakaan secara efektif dan efisien. Konsep komprehensif dari manajemen perpustakaan, di antaranya membutuhkan 
interpretasi tentang arti, sistem, dan makna dari perpustakaan perguruan tinggi.

Kegiatan pelayanan perpustakaan perguruan tinggi meliputi layanan teknis, layanan pemustaka, dan layanan administrasi yang sangat membutuhkan manajemen perpustakaan. Hal ini melalui fungsi manajemen yang terdiri dari kegiatan merencanakan, mengorganisasikan, melaksanakan, dan mengendalikan. Perpustakaan perguruan tinggi diharapkan dapat mencapai tujuan tri dharma, sesuai bidang pelayanan di antaranya bidang pendidikan, riset, informasi, dan administrasi. Kepala perpustakaan pun berperan mengelola sumber daya perpustakaan dan mengaplikasikan manajemen perpustakaan perguruan tinggi saat ini.

Berdasarkan paparan di atas, manajemen perpustakaan perguruan tinggi adalah manajemen yang dilaksanakan di perpustakaan perguruan tinggi melalui kegiatan perencanaan, pengorganisasian, penyusunan pegawai, pembinaan, pengoordinasian, komunikasi, motivasi, pengajuan anggaran, pengendalian, pengawasan, penilaian, dan pertanggungjawaban pelayanan yang berkualitas. Perpustakaan perguruan tinggi menerapkan prinsip, konsep, dan teori manajemen dalam usaha mewujudkan pelayanan perpustakaan yang efektif dan efisien. Maka, inti dari manajemen perpustakaan perguruan tinggi adalah manajemen yang efektif untuk mengelola perpustakaan melalui pengembangan potensi sumber daya perpustakaan. Manajemen perpustakaan sendiri merupakan pendekatan dalam pengembangan mutu sumber daya perpustakaan.
Untuk itu, kualitas pelayanan perpustakaan perguruan tinggi merupakan kebutuhan bagi pemustaka melalui pelayanan dan manajemen yang bagus. Akreditasi sebagai salah satu cara untuk mengukur kualitas sebuah pelayanan perpustakaan. Hal ini diperkuat melalui kebijakan akreditasi dari pemerintah.

"Akreditasi merupakan proses legalisasi dan sertifikasi yang dilakukan lembaga akreditasi kepada perpustakaan yang memenuhi kriteria yang telah ditetapkan" (Peraturan Perpustakaan Nasional Nomor 10 Tahun 2018 Tentang Instrumen Akreditasi Perpustakaan Perguruan Tinggi, 2018).

Jadi, perpustakaan perguruan tinggi membutuhkan kemauan intern untuk mengajukan akreditasi kepada lembaga nasional, contohnya perpustakaan nasional. Lembaga ini akan menilai apakah perpustakaan telah memenuhi standar nasional yang ditetapkan negara dalam mendapatkan pengakuan formal.

Peningkatan mutu formal di perpustakaan perguruan tinggi pun dapat dilakukan melalui proses kegiatan akreditasi dari Perpustakaan Nasional Republik Indonesia yang bertujuan meningkatkan kualitas perpustakaan. Adapun bagian perpustakaan yang dinilai di antaranya koleksi, sarana dan prasarana, layanan, Sumber Daya Manusia, pengelolaan, dan penguatan perpustakaan yang ditetapkan dan bersifat terbuka oleh Lembaga Akreditasi Perpustakaan Nasional. Lembaga ini akan menilai standar minimal kesesuaian suatu perpustakaan.

Hasil penilaian akreditasi merupakan wujud pertanggungjawaban kepada semua pihak yang berkepentingan 
terhadap perpustakaan, di antaranya mahasiswa, pendidik, pemimpin lembaga, dan komunitas pendidikan. Maka perpustakaan harus memiliki tujuan yang jelas, sanggup mencapai tujuan, dan tetap melanjutkan keberhasilan pelayanan. Perpustakaan melalui akreditasi akan memperlihatkan keunikan yang dimilikinya, menunjukkan peringkat mutu perpustakaan, dan menggambarkan pencapaian kualitas pelayanan yang telah dilakukan perpustakaan. Dengan demikian, perpustakaan yang telah dilakukan akreditasi akan menerima pengakuan dari masyarakat dan lebih percaya diri dalam mengembangkan kualitas pelayanan.

Perpustakaan pun terus meningkatkan citra perpustakaan dan memperhatikan bagian yang dinilai akreditasi lainnya, seperti standar, kebijakan dan prosedur perpustakaan (Sulistyo-Basuki, 2013). Pemustaka sangat percaya kepada perpustakaan yang telah menerima akreditasi. Hal ini menunjukkan bahwa sebuah perpustakaan telah memiliki kualitas pelayanan yang baik. Akreditasi perpustakaan memiliki beberapa manfaat, seperti pengembangan kualitas perpustakaan, pemenuhan standar perpustakaan, motivasi pelayanan perpustakaan lebih baik dan profesional, memperkuat citra perpustakaan, penumbuhan kepercayaan pemustaka terhadap pelayanan perpustakaan, dan membangun infrastruktur perpustakaan dalam meningkatkan anggaran. Mutu perpustakaan akan terjamin melalui kegiatan akreditasi (Krismayani, 2019).

Selain itu, akreditasi telah memunculkan beberapa fenomena di masyarakat. Pertama, perpustakaan perguruan tinggi dalam akreditasi memilih swaregulasi perpustakaan daripada peraturan pemerintah. Kedua, semua stakeholder perpustakaan memiliki kemauan mendukung tercapainya sistem penjaminan mutu perpustakaan. Ketiga, perpustakaan menganggap lembaganya belum berkualitas apabila belum melaksanakan akreditasi. Untuk itu, akreditasi diharapkan dapat mengurangi jumlah perpustakaan yang tidak sesuai dengan pelayanan publik.

Penelitian mengenai akreditasi perpustakaan perguruan tinggi telah diteliti beberapa peneliti. Pertama, penelitian Adetunla and Familusi (2017) mengenai proses akreditasi perpustakaan Universitas Nigeria, di mana menggunakan standar akademik maksimum yang seragam. Selain itu, Adetunla and Familusi (2017) pun meneliti dampak akreditasi terhadap pertumbuhan perpustakaan perguruan tinggi Nigeria. Hasil penelitiannya mengungkapkan bahwa ada kekurangan dana yang memengaruhi kinerja optimal perpustakaan perguruan tinggi Nigeria. Perpustakaan sulit mendapatkan dana hingga pelaksanaan akreditasi yang semakin dekat. Namun demikian, akreditasi bermanfaat bagi perpustakaan untuk meningkatkan sumber informasi perpustakaan dan meningkatkan tampilan perpustakaan.

Akreditasi perpustakaan adalah kegiatan yang memiliki tujuan dalam memberikan penilaian kepada semua kegiatan pengelolaan perpustakaan sesuai ukuran standar mutu tertentu (Nurohman, 2016). Standar sebagai acuan ukuran sebuah kualitas. Maka, perpustakaan perguruan tinggi ketika mengelola akreditasi berarti harus melakukan konsep akreditasi berupa manajemen penyelenggaraan perpustakaan melalui enam komponen akreditasi dalam rangka 
mewujudkan perpustakaan yang berkualitas.

Perpustakaan yang berhasil memenuhi standar akreditasi akan menerima hasil akreditasi yang baik (Komarudin, 2016). Sertifikat akreditasi sendiri diberikan Lembaga Akreditasi Perpustakaan Nasional (LAP-N) yang menunjukkan hasil formal akreditasi suatu perpustakaan. Ketika perpustakaan mendapatkan hasil akreditasi, perpustakaan membuat hal ini sebagai motivasi dari pihak manajemen untuk kemajuan perpustakaan yang lebih baik lagi. Maka, hasil penilaian akreditasi harus ditingkatkan dan terus dipertahankan supaya ada peningkatan kualitas perpustakaan.

Kedua, penelitian Nuriana and Amelia (2019) yang menggunakan metode sharing best practice yaitu penerapan konsep teknologi yang sering digunakan individu maupun kelompok. Berdasarkan penelitian ini menyatakan bahwa, akreditasi merupakan branding perpustakaan untuk mendongkrak minat generasi milenial pada mahasiswa di suatu perguruan tinggi. Nilai akreditasi perpustakaan yang baik akan memberi kepercayaan pada mahasiswa era milenial untuk memanfaatkan perpustakaan sebagai sumber belajar.

Sesuai dua penelitian terdahulu di atas, perpustakaan sangat penting melakukan akreditasi. Namun, kedua penelitian terdahulu ini baru membahas mengenai studi kasus perpustakaan dalam penyiapan akreditasi dan dampak akreditasi berupa branding di perpustakaan. Adapun penelitian ini mengenai manajemen akreditasi perpustakaan di perguruan tinggi belum banyak diteliti. Manajemen akreditasi perpustakaan perguruan tinggi adalah suatu topik penelitian populer di kalangan lembaga perpustakaan perguruan tinggi. Manajemen akreditasi perpustakaan perguruan tinggi penting dilakukan untuk mempersiapkan pelayanan perpustakaan masa depan yang berkualitas berdasarkan kesesuaian standar perpustakaan perguruan tinggi dan penilaian akreditasi.

Dengan demikian, penelitian ini bertujuan untuk mengetahui bagaimana implementasi manajemen akreditasi perpustakaan perguruan tinggi berstandar nasional di Universitas Negeri Malang melalui proses perencanaan, proses pengorganisasian, proses pelaksanaan, dan proses pengawasan program kegiatan akreditasi. Peneliti melakukan penelitian implementasi manajemen akreditasi perpustakaan perguruan tinggi dilakukan agar mendapatkan informasi, gambaran, hingga dapat memberikan analisis mengenai praktik pengelolaan sebuah akreditasi perpustakaan. Untuk itu, diharapkan dari penelitian ini dapat memperkaya kepustakaan di bidang manajemen akreditasi, khususnya kajian mengenai akreditasi perpustakaan perguruan tinggi.

\section{METODE PENELITIAN}

Penelitian ini menggunakan metode penelitian kualitatif deskriptif untuk mendeskripsikan dan mengungkapkan manajemen yang dilakukan Perpustakaan Universitas Negeri Malang dalam akreditasi perpustakaan perguruan tinggi. Metode kualitatif memiliki tujuan untuk menggambarkan dan menjelaskan kegiatan penelitian yang dilakukan (Fadli, 2021). Peneliti dalam setiap tahapan manajemen melakukan perencanaan hingga pengontrolan atas proses akreditasi perpustakaan yang dijelaskan secara lebih detail dan terperinci. Perpustakaan 
Universitas Negeri Malang dipilih sebagai lokasi penelitian karena perpustakaan ini sedang mengusulkan akreditasi dan memiliki sumber daya yang relatif sangat bagus untuk sebuah perpustakaan perguruan tinggi yang berkualitas.

Peneliti dalam teknik pengumpulan data menggunakan wawancara, observasi, dan pencarian dokumentasi untuk mendapatkan data secara mendalam pada fungsi manajemen yang diterapkan dalam akreditasi Perpustakaan Universitas Negeri Malang. Pemilihan informan dilakukan menggunakan teknik purposive sampling melalui wawancara langsung atau tanya jawab secara lisan. Jumlah informan terdiri terdiri dari 1 orang kepala perpustakaan, 1 orang ketua tim akreditasi, 1 orang sekretaris akreditasi, 2 orang penasihat, dan koordinator masingmasing komponen akreditasi.

Kegiatan observasi dilakukan terhadap semua Sumber Daya Manusia yang terlibat dalam kegiatan akreditasi perpustakaan. Setiap sikap dan perilaku terkait kegiatan akreditasi perpustakaan Universitas Negeri Malang adalah data penting untuk mendukung hasil penelitian yang dilakukan. Observasi merupakan salah satu cara dalam mengamati objek penelitian, di mana peneliti mengamati dan mencatat objek penelitian secara sistematika atas gejala atau fenomena dalam penelitian (Dwitasari et al., 2020). Peneliti mengamati proses akreditasi di Perpustakaan Universitas Negeri Malang dalam penerapan fungsi manajemen. Kegiatan studi dokumentasi merupakan penghimpunan dokumen terkait semua dokumen yang digunakan dalam kegiatan akreditasi, contohnya laporan kinerja perpustakaan dan Memorandum of Understanding $(\mathrm{MoU})$ atau nota kesepahaman perpustakaan dengan lembaga lain yang berasal dari tata usaha perpustakaan.

Peneliti setelah memperoleh data penelitian, kemudian menyatukan dan mengolahnya berupa temuan penelitian. Data kualitatif yang telah diperoleh selanjutnya dianalisis menggunakan teori yang berasal dari beberapa literatur. Semua data disusun, dihubungkan, direduksi, dan disajikan untuk mendapatkan kesimpulan proses akreditasi Perpustakaan Universitas Negeri Malang. Analisis data kualitatif terdiri dari reduksi data, penyajian data, dan kesimpulan untuk digunakan secara kontinu selama penelitian berlangsung (Rijali, 2018).

\section{HASIL DAN PEMBAHASAN}

Implementasi manajemen akreditasi perpustakaan perguruan tinggi berstandar nasional di Universitas Negeri Malang dilakukan melalui tahapan proses perencanaan, pengorganisasian, pelaksanaan, dan pengawasan. Pertama, proses perencanaan merupakan hal pertama dan utama dalam melakukan sebuah manajemen. Agar semua kegiatan dapat berjalan efektif dan efisien, semuanya harus direncanakan dengan baik. Perencanaan dalam akreditasi Perpustakaan Universitas Negeri Malang melibatkan seluruh tenaga perpustakaan, di antaranya kepala perpustakaan, ketua tim akreditasi, staf tata usaha, dan pustakawan.

"Kegiatan ini akan dilakukan oleh semua tenaga pustakawan dan kependidikan, yang terdiri dari saya sebagai kepala perpustakaan, ada juga ketua tim akreditasi, para pustakawan, staf tata usaha, dan tenaga kependidikan lainnya, 
khususnya dalam tim akreditasi" (D. Saryono, wawancara, March 17, 2020).

Perpustakaan untuk mencari solusi atas masalah yang dihadapi membutuhkan perencanaan partisipatif yang melibatkan semua sumber daya organisasi. Maka, warga perpustakaan terus melakukan kerja sama dalam merencanakan akreditasi. Setelah kepala perpustakaan dan tim akreditasi merancang seluruh komponen Perpustakaan Universitas Negeri Malang kemudian semuanya terlibat dalam kegiatan akreditasi perpustakaan.

Sesuai tabel 1, tahapan perencanaan meliputi perencanaan kinerja, perencanaan kebutuhan borang akreditasi, perencanaan tim akreditasi, dan perencanaan bukti fisik boring akreditasi. Kepala perpustakaan dalam kegiatan perencanaan kinerja, merencanakan kegiatan yang akan dilakukan dalam persiapan akreditasi, misalnya menggunakan rancangan waktu (timeplan). Kemudian, kepala perpustakaan dalam perencanaan kebutuhan borang akreditasi melakukan diskusi terhadap hal yang dibutuhkan dalam memenuhi instrumen sesuai pedoman yang telah disepakati.

\section{Tabel 1}

Perencanaan akreditasi Perpustakaan Universitas Negeri Malang

\begin{tabular}{ll}
\hline Tahapan & Kegiatan \\
\hline Perencanaan & 1. Perencanaan kinerja \\
& 2. Perencanaan kebutuhan \\
& borang akreditasi \\
& $\begin{array}{l}\text { 3. Perencanaan tim } \\
\text { akreditasi }\end{array}$
\end{tabular}

Sumber: Hasil penelitian, 2020

Perencanaan sangat penting dalam pekerjaan atau suatu kegiatan yang akan dilakukan. Perencanaan pun sebagai langkah yang menentukan dalam keberhasilan akreditasi Perpustakaan
Universitas Negeri Malang. Kegiatan akreditasi akan mendapatkan hasil maksimal jika direncanakan dengan sebaik-baiknya. Maka, kunci keberhasilan suatu program adalah perencanaan. Setiap organisasi termasuk Perpustakaan Universitas Negeri Malang wajib melakukan perencanaan dengan matang ketika melaksanakan kegiatan akreditasi. Perencanaan merupakan alat untuk memprediksi keberhasilan suatu tujuan yang hendak diraih dan sebagai pedoman dalam proses pengawasan kegiatan yang sedang dilakukan. Secara umum, semua tenaga perpustakaan merencanakan secara bersama-sama dalam kegiatan akreditasi agar kinerja yang dilakukan terarah dan dapat mencapai target yang diinginkan bersama.

Aktivitas dalam tahap perencanaan akan memotivasi tim akreditasi perpustakaan ketika melakukan tugas dengan penuh tanggung jawab sesuai bidang masing-masing. Pada gambar 1, setiap instrumen standar akreditasi telah direncanakan sesuai borang akreditasi agar kinerja tim akreditasi lebih terarah. Selain itu, tim akreditasi pun menyiapkan anggaran dan infrastruktur untuk melaksanakan proses akreditasi dapat lebih fokus dan jelas.

Kepala perpustakaan dalam kegiatan perencanaan tim akreditasi membentuk tim akreditasi. Kepala perpustakaan memilih anggota tim redaksi yang diberikan tanggung jawab untuk melengkapi setiap standar borang akreditasi. Tim akreditasi dibentuk untuk meningkatkan efektivitas dan efisiensi pelaksanaan program akreditasi melalui penyusunan perencanaan akreditasi perpustakaan dan untuk menghindari kegagalan. 
"Kami mengoptimalkan semua sumber daya perpustakaan untuk mendukung kegiatan akreditasi ini. Kami dengan menganalisis anggaran, sarana prasarana, sumber daya manusia, dan sebagainya, merencanakan strategi untuk kegiatan akreditasi kali ini" (D. Saryono, wawancara, April 14, 2020).

Untuk itu, perpustakaan dalam rangka mencapai tujuan organisasi yang efektif dan efisien membutuhkan analisis berbagai sumber daya organisasi, seperti anggaran, fasilitas dan infrastruktur, perundang-undangan, dan kebijakan publik agar strategi yang dilakukan organisasi lebih fokus. Dengan menggunakan sumberdaya dengan baik, organisasi dapat mencapai tujuannya (Hanafi, Almy, \& Siregar, 2018). Kepala perpustakaan dalam kegiatan perencanaan bukti fisik borang akreditasi akan mengumpulkan dokumen terkait bukti akreditasi yang dibutuhkan. Setiap komponen akreditasi akan ditetapkan target sasaran berupa bukti fisik yang harus dikumpulkan. Hal ini ditunjang strategi perencanaan yang dilakukan manajemen Perpustakaan Universitas Negeri Malang, seperti rapat dengan tim akreditasi. Tim akreditasi yang sering bertemu, akan lebih banyak peluang untuk saling bertukar ide dan menemukan solusi dalam melengkapi kebutuhan instrumen akreditasi. Apabila anggota tim akreditasi membutuhkan bantuan, maka anggota lainnya akan mudah membantu. Maka, tujuan perpustakaan, solusi terhadap masalah, dan tanggung jawab terhadap pekerjaan masing-masing anggota tim akreditasi perpustakaan dapat terfokus.

Sesuai hasil wawancara, tim akreditasi Perpustakaan Universitas Negeri Malang melakukan perencanaan secara struktural dan organisasi. Hal ini sesuai pernyataan informan.

“Konteks dasar yang sedang kami dalam perencanaan struktur tim akreditasi. Keefektifan tim akreditasi dapat dicapai melalui perencanaan struktur sesuai faktor kontekstual" (N. Nugrahini, wawancara, April 7, 2020).

Perpustakaan Universitas Negeri Malang melakukan rencana kerja sebagai bagian dari hasil perencanaan yang sudah dilakukan. Maka, setiap anggota tim akreditasi dibagikan tugasnya masingmasing. Rencana kerja merupakan hal penting dalam mengatur kerja yang tergabung dengan tim.

Kedua, proses pengorganisasian. Tahap pengorganisasian dalam manajemen sangat penting karena membuat posisi tugas lebih jelas dalam struktur organisasi. Organisasi akan dapat mencapai tujuannya secara efektif dan efisien jika dapat mendeteksi sumber daya yang dimiliki melalui penyeleksian, pengalokasian, dan pendistribusian jenis pekerjaan secara profesional. Tim akreditasi dalam proses pengorganisasian mempersiapkan dan membentuk hubungan kerja anggota organisasi. Hal ini dilakukan untuk mewujudkan kesatuan dalam memenuhi target yang telah disepakati dengan distribusi kerja yang profesional dalam bingkai struktur organisasi.

Pada tabel 2, proses pengorganisasian, terdiri dari pengelompokan standar nasional ke dalam instrumen akreditasi, pengorganisasian kerja tim akreditasi, dan pengorganisasian dokumen akreditasi. Kegiatan pengelompokan standar nasional ke dalam instrumen akreditasi merupakan rangkaian kegiatan pengelompokan standar nasional perpustakaan ke dalam instrumen akreditasi dan mempersiapkan distribusi standar nasional perpustakaan 
untuk mendukung tugas tim akreditasi dalam struktur organisasi. Tim akreditasi dalam bentuk struktur organisasi telah terbentuk pada tahap perencanaan, tetapi secara resmi mulai bertugas pada bulan Februari 2020.

Tabel 2

Pengorganisasian akreditasi Perpustakaan Universitas Negeri Malang

\begin{tabular}{ll}
\hline Tahapan & Kegiatan \\
\hline Pengorganisasian & 1. Pengelompokan standar \\
& nasional ke dalam \\
& instrumen akreditasi \\
& 2. Pengorganisasian kerja \\
& tim akreditasi \\
& 3. Pengorganisasian \\
& dokumen akreditasi
\end{tabular}

Sumber: Hasil penelitian, 2020

Kegiatan pengorganisasian kerja tim akreditasi ialah pembagian sumber daya manusia untuk bekerja melaksanakan akreditasi. Pustakawan telah meluangkan banyak waktu untuk bekerja keras menyiapkan akreditasi perpustakaan dan sangat menentukan dalam pembentukan struktur organisasi tim akreditasi. Maka, kegiatan akreditasi perpustakaan sangat membutuhkan waktu, tenaga dan pikiran. Maka, sumber daya manusia perpustakaan sangat dibutuhkan sekali yang siap bekerja keras dalam melaksanakan akreditasi. Tenaga perpustakaan Universitas Negeri Malang adalah tim inti akreditasi berjumlah sembilan orang yang mendampingi kepala subbagian tata usaha dan kepala perpustakaan. Tim akreditasi perpustakaan membutuhkan perhatian yang baik agar kinerja dalam kegiatan akreditasi dapat optimal.

Perpustakaan Universitas Negeri Malang sendiri belum memiliki pedoman baku dalam membuat struktur organisasi tim akreditasi internal. Tim akreditasi perpustakaan dibentuk sesuai kebutuhan untuk melengkapi borang setiap komponen akreditasi. Selanjutnya borang tersebut bermanfaat untuk memenuhi kelengkapan dan ketercapaian nilai akreditasi maksimal dari perpustakaan.

Pengorganisasian dokumen akreditasi sesuai dasar penilaian akreditasi perpustakaan terdiri dari enam standar nasional, di antaranya komponen standar koleksi, standar sarana prasarana, standar layanan, standar tenaga, standar manajemen, dan standar penguat. Setiap pustakawan memiliki kemampuan dan kesanggupan untuk melengkapi seluruh instrumen sebagai dasar distribusi tugas yang dilakukan. Tugas dan fungsi anggota tim akreditasi diperjelas dalam struktur tim akreditasi agar tidak ada perbedaan dalam melengkapi instrumen akreditasi perpustakaan.

"Pengorganisasian tim disusun saat waktu rapat kinerja akreditasi. Susunan tim akreditasi terkait tugas dan fungsinya disesuaikan dengan kecakapan personal dalam memenuhi kebutuhan komponen akreditasi. Di luar tugas dan fungsi tim akreditasi, juga dibahas bersama masing-masing bukti fisik dari instrumen akreditasi" (N. Nugrahini, wawancara, June 4, 2020).

Setiap anggota organisasi memiliki fungsi dan tugasnya masing-masing yang saling berinteraksi dengan sistem tertentu. Pustakawan memiliki kompetensi dan kesiapan dalam melengkapi seluruh arsip, dokumen, dan bukti fisik untuk memenuhi instrumen akreditasi sebagai dasar untuk pembagian tugas tim. Bukti fisik untuk komponen akreditasi dapat dilengkapi dengan membentuk tim kerja yang membantu dalam proses penyediaan dokumen. 
Perpustakaan Universitas Negeri Malang sendiri memiliki tujuan untuk mencapai penilaian akreditasi yang memuaskan melalui pengorganisasian anggota tim akreditasi dan pengorganisasian bukti fisik untuk kelengkapan komponen akreditasi.

"Untuk memenuhi borang akreditasi, saya sebagai ketua tim akreditasi bertanggung jawab untuk menyiapkan dokumen bukti fisik" (N. Nugrahini, wawancara, April 16, 2020).

Pihak manajemen menggunakan dokumentasi dalam pengambilan keputusan. Bagian tata usaha dapat menginventarisasi, mengelompokkan, menyusun, dan menyediakan sarana temu balik suatu dokumen (Nugrohoadhi, 2015). Saat bukti fisik perpustakaan sudah terkumpul, tim akreditasi membagi pekerjaan agar lebih efektif.

Tim akreditasi membuat daftar instrumen akreditasi yang ingin dipenuhi dan segera melengkapinya. Hal ini merupakan kegiatan pengorganisasian yang diterapkan kepada seluruh anggota tim. Bukti fisik dari butir instrumen akreditasi dikelompokkan sesuai komponen penilaian akreditasi. Tim akreditasi menyiapkan semua bukti fisik berdasarkan indikator pada standar nasional perpustakaan dan mengumpulkannya dalam satu dokumen.

Perpustakaan Universitas Negeri Malang melakukan pengorganisasian struktural dan pengklasifikasian instrumen akreditasi secara terstruktur dan tertata. Bentuk struktur tim akreditasi perpustakaan sangat sederhana, yang terdiri dari kepala perpustakaan sebagai penanggung jawab, penasihat, ketua tim akreditasi, sekretaris, koordinator komponen, dan anggota.
Pengorganisasian bukti fisik menggunakan map folder sesuai jumlah butir instrumen akreditasi. Map folder tersebut digunakan sebagai alat bantu pengelompokan komponen akreditasi sesuai petunjuk teknis pengisian. Pada tahap ini, bukti fisik masing-masing standar nasional perpustakaan sudah terbentuk sesuai komponen akreditasi. Adapun butir instrumen akreditasi dibagikan kepada masing-masing anggota tim akreditasi. Selanjutnya, anggota tim akreditasi mengumpulkan ke dalam map folder yang sudah diberikan keterangan sesuai komponen akreditasi.

Sesuai temuan penelitian, kunci pengorganisasian kegiatan akreditasi di Perpustakaan Universitas Negeri Malang ialah anggota tim saling membantu, saling memahami, san saling menjaga hubungan komunikasi. Tim akreditasi merupakan penguat hubungan silaturahmi dan komunikasi melalui sikap saling terbuka dan jujur ketika menghadapi kesalahan dalam komunikasi.

“Dalam tim akreditasi ini, kami selalu bekerja sama, menyampaikan pendapat, dan tetap membangun komunikasi yang baik dalam melengkapi borang dan bukti fisik untuk akreditasi" (M. Safii, wawancara, April 14, 2020).

Perpustakaan Universitas Negeri Malang memiliki komitmen dalam mendapatkan nilai akreditasi yang baik. Hal ini ditentukan komunikasi antara semua staf perpustakaan. Pelaksanaan komunikasi hendaknya dilakukan secara intens dan bersemangat sehingga tujuan akreditasi mendapatkan hasil yang optimal (Rahayu, Retnaningdyastuti, \& Roshayanti, 2019).

Tim akreditasi perpustakaan menguraikan pembagian tugas berdasarkan 
tiap komponen akreditasi berupa kelengkapan bukti fisik yang disertakan dalam kegiatan akreditasi. Adapun dasar pengorganisasian bukti fisik agar mudah dipahami melalui pengklasifikasian acuan standar nasional perpustakaan dan petunjuk teknis akreditasi. Berdasarkan hasil observasi, dokumentasi, dan wawancara yang sudah dilakukan peneliti, Perpustakaan Universitas Negeri Malang telah melakukan tahap pengorganisasian dengan baik. Peneliti melihat bahwa struktur organisasi dan perincian tugas setiap anggota tim akreditasi perpustakaan telah dilaksanakan sesuai tugas dan fungsi.

Ketiga, proses pelaksanaan.

Pelaksanaan kegiatan akreditasi merupakan kegiatan yang dilakukan setelah merencanakan dan mengorganisasikan akreditasi. Perpustakaan telah menyepakati bersama dalam penerapan kegiatan akreditasi perpustakaan. Di mana semua tim akreditasi perpustakaan bekerja keras dan saling bekerja sama satu dengan yang lain. Selain itu, penilaian akhir dari kegiatan akreditasi terhadap kinerja perpustakaan adalah pemenuhan kelengkapan dokumen akreditasi. Tim akreditasi perpustakaan melakukan pengarahan dalam pemenuhan seluruh borang komponen akreditasi sampai proses visitasi dari asesor yang ditunjuk perpustakaan nasional.

Pada tabel 3, proses pelaksanaan akreditasi, terdiri dari pemenuhan kelengkapan dokumen akreditasi, persiapan proses visitasi akreditasi, koreksi terhadap borang akreditasi, dan pelaksanaan proses self assessment akreditasi.
Tabel 3

Pelaksanaan akreditasi Perpustakaan Universitas Negeri Malang

\begin{tabular}{ll}
\hline Tahapan & Kegiatan \\
\hline Pelaksanaan & 1. Pemenuhan kelengkapan \\
& dokumen akreditasi \\
& 2. Persiapan proses visitasi \\
& akreditasi \\
& 3. Koreksi terhadap borang \\
& akreditasi \\
& 4. Pelaksanaan proses self \\
& assessment akreditasi \\
\hline
\end{tabular}

Sumber: Hasil penelitian, 2020

Kegiatan pemenuhan kelengkapan dokumen akreditasi dilakukan tim akreditasi perpustakaan dengan membaca dan memahami seluruh isi petunjuk teknis penyelenggaraan akreditasi perpustakaan perguruan tinggi. Hal ini dilakukan untuk memenuhi kelengkapan borang komponen akreditasi. Pustakawan dibantu staf tata usaha bertanggung jawab melengkapi enam komponen standar nasional perpustakaan yang berupaya sekuat tenaga agar borang sebagai indikator instrumen akreditasi terpenuhi.

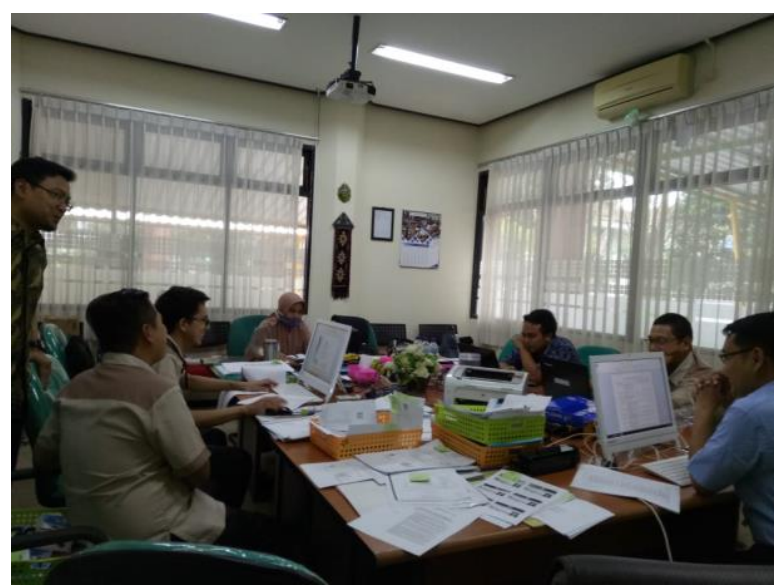

Gambar 2. Kegiatan pengisian borang Sumber: Dokumentasi tata usaha, 2020 
Kelengkapan dokumen dan keperluan terkait kegiatan akreditasi perpustakaan merupakan hasil kerja sama antara pustakawan dan staf tata usaha.

"Alhamdulillah, berkat kerja keras dan kerja sama tim akreditasi, kami dapat memenuhi borang dan mengumpulkan bukti fisik akreditasi dengan mudah" (A. Masud, wawancara, May 14, 2020).

Kerja sama tim bertujuan untuk menemukan kekuatan diri, belajar menghargai orang lain, membuat pikiran terbuka, dan membangun pemahaman bersama (Fauzi, 2017). Pustakawan yang bertugas melengkapi instrumen akreditasi selalu bekerja sama dengan pihak tata usaha untuk melakukan pemenuhan atas bukti fisik tersebut. Pustakawan dibantu tata usaha mempelajari petunjuk teknis akreditasi untuk memenuhi butir instrumen akreditasi.

Perpustakaan Universitas Negeri Malang dalam persiapan proses visitasi akreditasi melakukan analisis kembali kelengkapan yang telah dikumpulkan sesuai ketentuan akreditasi. Semua ketentuan teknis dari Lembaga Akreditasi Perpustakaan-Nasional (LAP-N) mengatur tahap akreditasi dari awal hingga akhir. Ketentuan akreditasi dari Lembaga Akreditasi Perpustakaan-Nasional tersebut sebagai pedoman Perpustakaan Universitas Negeri Malang untuk menghindari terjadinya kesalahan dalam pelaksanaan kegiatan akreditasi.

Kepala perpustakaan dan tim akreditasi selalu menjaga lingkungan kerja yang kondusif agar dapat mencapai kegiatan akreditasi yang efektif dan efisien.

"Kami selalu menjaga suasana dan semangat kerja yang kondusif agar kinerja tim akreditasi tetap terjaga dengan baik" (D. Saryono, wawancara, May 12, 2020).

Tim akreditasi selalu menjaga komunikasi yang harmonis antara anggota tim. Hal ini telah memengaruhi kinerja perpustakaan dalam pelaksanaan akreditasi. Kinerja organisasi dapat dipengaruhi oleh iklim organisasi (Mukhtar \& Asmawiyah, 2019). Saat pelaksanaan akreditasi, tim bekerja sama menciptakan iklim kerja yang kondusif. Hal ini ternyata berpengaruh pada peningkatan kinerja tim akreditasi.

Motivasi dan fokus kinerja tim sesuai prinsip dan fungsi merupakan iklim organisasi yang harus terus dipertahankan. Pendekatan secara individu dan kelompok sebagai cara untuk menciptakan lingkungan yang baik bagi tim akreditasi. Maka, diharapkan seluruh tugas dan tanggung jawab pelaksanaan akreditasi dapat dilakukan dengan baik. Kepala perpustakaan dan tim akreditasi selalu mengingatkan bahwa dalam pelaksanaan akreditasi agar tetap berpedoman pada panduan akreditasi sehingga kesalahan dalam memenuhi komponen akreditasi dapat dikurangi.

"Pedoman akreditasi perpustakaan dari Lembaga Akreditasi Perpustakaan-Nasional (LAP-N) telah memberikan kami arahan untuk melakukan kegiatan akreditasi ini. Seluruh tahapan akreditasi telah dijelaskan dalam pedoman tersebut, sehingga kami memiliki kesatuan tindakan dalam memenuhi setiap komponen akreditasi. Pedoman tersebut juga sebagai rambu dalam mencegah kesalahan pengisian borang akreditasi. Dan kami selalu mempunyai tekad dalam menyajikan layanan perpustakaan yang bermutu." 
(A. A. Kosasih, wawancara, June 2, 2020).

Tim akreditasi Perpustakaan Universitas Negeri Malang dalam proses pelaksanaan sudah melakukan sesuai petunjuk umum dan teknis akreditasi perpustakaan perguruan tinggi yang ditetapkan Lembaga Akreditasi Perpustakaan Nasional. Semua tenaga perpustakaan pun berperan aktif dalam pelaksanaan akreditasi. Selain itu, kepala perpustakaan bertanggung jawab penuh atas kegiatan akreditasi.

Perpustakaan Universitas Negeri Malang dalam kegiatan koreksi terhadap borang akreditasi telah melakukan koreksi terkait borang akreditasi yang sudah dilengkapi komponen akreditasi sesuai standar nasional perpustakaan perguruan tinggi. Setiap penanggung jawab komponen akreditasi mengumpulkan dan menyiapkan dokumen secara menyeluruh. Tim akreditasi dalam memenuhi setiap borang instrumen akreditasi selalu berpedoman pada petunjuk teknis penyelenggaraan akreditasi.

Perpustakaan Universitas Negeri Malang dalam proses pelaksanaan akreditasi melakukan pemenuhan kelengkapan bukti fisik akreditasi, proses visitasi, dan penilaian kinerja perpustakaan. Koordinator setiap komponen akreditasi mengumpulkan bukti fisik pada tahap ini. Bukti fisik yang sudah sesuai standar nasional perpustakaan kemudian dilakukan proses self assesment untuk pelaksanaan kegiatan akreditasi.

Perpustakaan Universitas Negeri Malang dalam kegiatan pelaksanaan proses self assessment akreditasi melakukan penghitungan dalam setiap komponen. Hal ini dilihat apakah sudah sesuai dengan nilai akreditasi yang diharapkan atau belum. Apabila nilai akreditasinya belum sesuai rencana, maka masingmasing koordinator komponen akan melengkapi detail borang agar nilai yang dihasilkan sesuai dengan yang diharapkan.

Berdasarkan hasil penelitian, peneliti mengungkapkan bahwa tahap pelaksanaan akreditasi di Perpustakaan Universitas Negeri Malang sudah sesuai petunjuk teknis akreditasi, yang terdiri dari kelengkapan instrumen akreditasi, menyatukan kebutuhan proses kegiatan akreditasi, dan menyertakan bukti fisik dalam memenuhi komponen akreditasi. Proses pelaksanaan akreditasi yang efektif dan efisien memerlukan kerja sama yang saling mendukung dan hubungan kerja yang harmonis antara kepala perpustakaan dengan tim akreditasi sehingga hasil penilaian akreditasi dapat memuaskan.

Setelah menempuh tahap pelaksanaan, keempat adalah proses pengawasan. Proses pengawasan terkait fungsi manajemen akreditasi yang dilakukan Perpustakaan Universitas Negeri Malang. Hal ini dilakukan kepala perpustakaan dalam menghadapi proses akreditasi perpustakaan untuk membangun dan meraih hasil optimal akreditasi perpustakaan. Selain itu, pengawasan dilakukan juga untuk membuat layanan perpustakaan lebih berkualitas dan terpercaya. Proses pengawasan terhadap pelaksanaan kegiatan akreditasi perlu dijalankan untuk mengetahui tingkat kesuksesan dalam memenuhi komponen akreditasi, dan pelaksanaan perbaikan atau evaluasi ketika menemukan kendala dalam kegiatan akreditasi perpustakaan.

Pengawasan terhadap kegiatan akreditasi bertujuan untuk menstabilkan 
kinerja tim akreditasi agar dapat berjalan efektif dan efisien mungkin. Maka, diharapkan Perpustakaan Universitas Negeri Malang melakukan pengawasan dengan baik yang mendukung tujuan jangka pendek dan jangka panjang lembaga. Kepala perpustakaan dalam kegiatan akreditasi ini memang memiliki tujuan perpustakaan berhasil mendapatkan nilai yang memuaskan. Setiap anggota tim akreditasi perpustakaan tentu memiliki target dalam hasil penilaian akreditasi.

Proses pengawasan dalam manajemen merupakan tahapan untuk menilai apakah perencanaan, pengorganisasian, dan pelaksanaan kegiatan akreditasi perpustakaan sudah dilakukan dengan sebaik-baiknya. Hal tersebut apakah sudah sesuai buku pedoman penyelenggaraan akreditasi perpustakaan di perguruan tinggi. Keberhasilan penerapan standar nasional perpustakaan atau proses evaluasi dilakukan pada tahap pengawasan yang bertujuan menemukan solusi yang tepat atas kelengkapan semua komponen akreditasi perpustakaan.

\section{Tabel 4}

Pengawasan akreditasi Perpustakaan Universitas Negeri Malang

\begin{tabular}{|c|c|}
\hline Tahapan & Kegiatan \\
\hline Pengawasan & $\begin{array}{l}\text { 1. Evaluasi kesesuaian borang } \\
\text { akreditasi dengan standar } \\
\text { nasional } \\
\text { 2. Evaluasi administrasi } \\
\text { 3. Evaluasi anggaran } \\
\text { 4. Evaluasi kinerja tim } \\
\text { akreditasi } \\
\text { 5. Pemeriksaan kelengkapan } \\
\text { bukti fisik }\end{array}$ \\
\hline
\end{tabular}

Sumber: Hasil Penelitian, 2020

Sesuai tabel 4, proses pengawasan terdiri dari kegiatan evaluasi kesesuaian borang akreditasi dengan standar nasional, evaluasi administrasi, evaluasi anggaran, evaluasi kinerja tim akreditasi, dan pemeriksaan kelengkapan bukti fisik. Perpustakaan Universitas Negeri Malang dalam kegiatan evaluasi kesesuaian borang akreditasi standar nasional, menyesuaikan setiap item borang akreditasi dengan buku pedoman akreditasi berstandar nasional. Adapun Perpustakaan Universitas Negeri Malang dalam kegiatan evaluasi administrasi memeriksa apakah administrasi dan persuratan yang dibutuhkan untuk mendukung bukti fisik sudah dibuat.

Selain itu, Perpustakaan Universitas Negeri Malang dalam kegiatan evaluasi anggaran memeriksa pengeluaran dan pos anggaran yang telah dibelanjakan untuk kegiatan akreditasi perpustakaan. Kemudian, Perpustakaan Universitas Negeri Malang dalam kegiatan evaluasi kinerja tim akreditasi menilai kinerja setiap koordinator komponen akreditasi sesuai target pencapaian tujuan akreditasi. Terakhir, Perpustakaan Universitas Negeri Malang dalam kegiatan pemeriksaan kelengkapan bukti fisik memeriksa bukti fisik borang akreditasi yang telah disertakan.

Kepala perpustakaan melakukan pengawasan bersifat internal berupa pengawasan administrasi, anggaran, dan proses kegiatan akreditasi yang dilakukan tim akreditasi perpustakaan. Tim akreditasi perpustakaan dan staf tata usaha memiliki tugas dan tanggung jawab membantu terlaksananya proses pengawasan. Kepala perpustakaan melakukan evaluasi terhadap kinerja tim akreditasi setiap hari Selasa dan Kamis. Selain itu, kepala perpustakaan mengevaluasi kinerja anggota tim akreditasi melalui pemeriksaan kelengkapan bukti fisik dari instrumen 
akreditasi apakah sudah terpenuhi atau belum. Kepala perpustakaan pun memberikan tenggat waktu (deadline) pada anggota tim akreditasi dalam menyelesaikan tugas yang telah diberikan. Pimpinan dapat mengetahui hasil pekerjaan yang dilakukan anggotanya sesuai rencana, arahan, tujuan, atau kebijakan yang sudah ditentukan melalui pengawasan umpan balik (Rahman, Rahim, \& Elfiansyah, 2018).

Kepala perpustakaan terus memantau proses pengawasan kegiatan akreditasi, misalnya kepala perpustakaan akan menindaklanjuti dokumen akreditasi yang belum lengkap, belum terealisasi, bukti fisik, dan kebutuhan komponen akreditasi lainnya. Kinerja tim akreditasi dan pustakawan selalu dilihat sebagai kinerja positif oleh kepala perpustakaan. Kepala perpustakaan terus mengingatkan tim akreditasi agar selalu berpedoman pada petunjuk teknis pelaksanaan akreditasi perguruan tinggi sehingga keseluruhan tugas tim akreditasi dapat sejalan dengan kegiatan akreditasi.

Kepala perpustakaan sangat penting melakukan proses pengawasan agar tim akreditasi bekerja lebih fokus dan termotivasi untuk mengerjakan tugasnya dengan baik. Dengan demikian, tolak ukur keberhasilan tim akreditasi adalah pengawasan yang dilakukan kepala perpustakaan, di mana selalu ada perbaikan setelah dilakukan proses pengawasan. Kepala perpustakaan berkeyakinan untuk mendapatkan hasil yang memuaskan. Maka, kepala perpustakaan melakukan pengawasan melalui cara yang humanis terhadap proses kerja tim akreditasi, mulai dari perencanaan hingga pelaksanaan di lapangan. Hasil akhir penilaian akreditasi pun akan memuaskan jika proses pemenuhan semua komponen akreditasi dilakukan dengan baik pula.

Kepala perpustakaan membuat jadwal pemeriksaan terhadap pemenuhan kelengkapan komponen akreditasi untuk memantau kinerja yang dilakukan tim akreditasi. Selain itu, kepala perpustakaan menyediakan forum tanya jawab dan diskusi untuk mengatasi komponen akreditasi yang belum selesai sehingga anggota lain dapat saling membantu dan memberi masukan dalam penyediaan bukti fisik. Suasana kerja dalam kegiatan akreditasi lebih kondusif dan terkendali melalui diskusi antar anggota tim. Kepala Perpustakaan Universitas Negeri Malang melakukan pengawasan terhadap kinerja tim akreditasi agar akreditasi perpustakaan mendapatkan hasil yang memuaskan. Maka, kepala perpustakaan mengambil langkah di antaranya menetapkan standar, mengadakan evaluasi, dan melakukan koreksi agar kelengkapan komponen akreditasi dapat terpenuhi dengan baik.

Tujuan pengawasan adalah menetapkan kinerja standar dan mengambil tindakan perbaikan agar penggunaan sumber daya dapat terpenuhi secara efektivitas dan efisiensi.

"Tujuan kami sebagai tim akreditasi dapat terwujud dengan pengawasan yang serius dan fokus dari bapak kepala perpustakaan. Kami menargetkan hasil akreditasi yang memuaskan yaitu nilai A, oleh karenanya kami bertekad untuk memberikan yang terbaik dalam akreditasi kali ini. Bapak kepala perpustakaan juga sudah menjalankan pengawasan yang baik kepada kinerja kami" (A. Qorni, wawancara, June 9, 2020). 
Kepala perpustakaan melakukan proses pengawasan untuk menghindari pekerjaan akreditasi yang menyimpang dari petunjuk teknis, memperbaiki proses kerja akreditasi yang lebih efektif dan efisien, dan memperbaiki kinerja tim akreditasi. Perpustakaan Universitas Negeri Malang sendiri melakukan proses pengawasan sejenis pengawasan yang melekat, dilakukan kepala perpustakaan terhadap tim akreditasi perpustakaan, staf tata usaha, dan pustakawan yang terlibat. Semua individu diharapkan bertanggung jawab dan mengawasi secara mandiri setiap kinerjanya agar termotivasi dalam melakukan kegiatan akreditasi perpustakaan. Tahap pengawasan pun sebagai strategi untuk menghindari berbagai penyimpangan terhadap keberadaan input, proses, dan output akreditasi Perpustakaan Universitas Negeri Malang.

\section{SIMPULAN}

Perpustakaan Universitas Negeri Malang telah melakukan dengan baik dalam implementasi manajemen akreditasi melalui perencanaan, pengorganisasian, pelaksanaan dan pengawasan. Implementasi perencanaan kinerja dilakukan pustakawan. Adapun kepala perpustakaan memilih anggota tim redaksi yang diberikan tanggung jawab untuk melengkapi setiap standar borang akreditasi yang berisi instrumen standar akreditasi. Implementasi pengorganisasian akreditasi antara lain berisi kegiatan pengelompokan standar nasional ke dalam instrumen akreditasi untuk mendukung tugas tim akreditasi dalam struktur organisasi. Tim akreditasi yang mulai bertugas Februari 2020 berjumlah sembilan orang terdiri dari kepala perpustakaan, tenaga perpustakaan, dan kepala subbagian tata usaha. Tim akreditasi perpustakaan masih membutuhkan perhatian yang baik agar kinerja dalam kegiatan akreditasi dapat optimal. Pengorganisasian dokumen akreditasi sesuai dasar penilaian akreditasi perpustakaan yang terdiri dari enam standar nasional, komponen standar koleksi, standar sarana prasarana, standar layanan, standar tenaga, standar manajemen, dan standar penguat. Pustakawan dan staf tata usaha dalam implementasi pelaksanaan akreditasi dalam melakukan pemenuhan kelengkapan bukti fisik akreditasi, proses visitasi, dan penilaian kinerja perpustakaan pemenuhan kelengkapan dokumen akreditasi dilakukan. Adapun Perpustakaan Universitas Negeri Malang dibantu koordinator pelaksanaan akreditasi menganalisis dan melakukan koreksi kembali kelengkapan akreditasi sesuai dari Lembaga Akreditasi Perpustakaan-Nasional (LAP-N). Kepala Perpustakaan Universitas Negeri Malang dibantu tim akreditasi dan tata usaha melakukan pengawasan akreditasi dalam penyesuaian item borang akreditasi dengan buku pedoman akreditasi berstandar nasional, memeriksa administrasi dan persuratan sebagai bukti fisik akreditasi, memeriksa pengeluaran dan pos anggaran, dan penilaian kinerja setiap koordinator komponen akreditasi. Penelitian ini belum memberikan kajian mendalam tentang komponen borang akreditasi perpustakaan perguruan tinggi. Namun, penelitian ini dapat menentukan pola akreditasi perpustakaan perguruan tinggi dalam memenuhi komponen borang akreditasi. Selanjutnya, dibutuhkan suatu penelitian yang dapat memberikan rekomendasi spesifik terkait pengisian komponen borang akreditasi perpustakaan 
perguruan tinggi. Penelitian berikutnya dapat berkonsentrasi mengenai bagaimana cara manajemen memenuhi komponen borang akreditasi dan bagaimana peningkatan kualitas pelayanan perpustakaan setelah akreditasi.

\section{DAFTAR PUSTAKA}

Adetunla, G., \& Familusi, E. (2017). The impact of accreditation on the growth of academic libraries in Nigeria. Library Philosophy and Practice, 1(1), 118. Retrieved from https://digitalcommons.unl.edu/libp hilprac/1591/

Aray, M., Lumolos, J., \& Sampe, S. (2019). Implementasi program bantuan anak asuh di Kecamatan Kotamobagu Timur. Jurnal Eksekutif, 3(3), 1-9. Retrieved from https:/ / ejournal.unsrat.ac.id/index.p hp/jurnaleksekutif/article/view/267 44/26341

Asmosatunah, B. (2018). Rekonstruksi citra dan eksistensi perpustakaan: Kajian peningkatan dan penguatan kualitas perpustakaan perguruan tinggi dalam perspektif manajemen. Libraria: Jurnal Ilmu Perpustakaan Dan Informasi, 7(1), 75-91.

https://doi.org/10.13140/RG.2.2.118 47.75689

Dwitasari, P., Darmawati, N. O., Noordyanto, N., Sittasya, V. A., Zulraniyah, W., Raihanah, F. D., \& Karim, A. A. (2020). Penggunaan metode observasi partisipan untuk mengidentifikasi permasalahan operasional Suroboyo Bus Rute MerrITS. Jurnal Desain Idea: Jurnal Desain Produk Industri Institut Teknologi Sepuluh Nopember Surabaya, 19(2), 5357.

https://doi.org/10.12962/iptek_desai n.v19i2.7943

Fadli, M. R. (2021). Memahami desain metode penelitian kualitatif. HUMANIKA: Kajian Ilmiah Mata Kuliah Umum, 21(1), 33-54. https:// doi.org/10.21831/hum.v21i1. 38075

Fatmawati, E. (2016). Kerja sama di antara SDM perpustakaan untuk menuju layanan prima dan unggul. Jurnal Pustaka Ilmiah, 2(1), 102-108. https:// doi.org/10.20961/jpi.v2i1.331 32

Fauzi, M. (2017). Peningkatan kerjasama dan prestasi belajar matematika materi bangun datar melalui model pembelajaran kooperatif tipe Team Game Tournament (TGT) di kelas VI Sekolah Dasar (Skripsi)

[Universitas Muhammadiyah, Purwokerto]. http://repository.ump.ac.id/1123/1/ COVER.pdf

Hanafi, A. S., Almy, C., \& Siregar, M. T. (2018). Pengaruh gaya kepemimpinan dan motivasi kerja terhadap kinerja pegawai. Jurnal Manajemen Industri Dan Logistik (JMIL), 2(1), 52-61. https:// doi.org/10.30988/jmil.v2i1.25 Peraturan Perpustakaan Nasional Nomor 10 Tahun 2018 Tentang Instrumen Akreditasi Perpustakaan Perguruan Tinggi. 13 Maret 2018. Jakarta. Retrieved from https://jdih.perpusnas.go.id/detail/1 62

Komarudin. (2016). Akreditasi perpustakaan perguruan tinggi: Pengalaman Perpustakaan STAIN Kediri. PUSTAKALOKA: Jurnal Kajian Informasi \& Perpustakaan, 8(1), 13-31. https:// doi.org/10.21154/pustakalok a.v8i1.454

Krismayani, I. (2019). Analisis kesesuaian instrumen akreditasi perpustakaan 
sekolah terhadap ketentuan standar nasional perpustakaan sekolah menengah atas. Anuva: Jurnal Kajian Budaya, Perpustakaan, Dan Informasi, 3(2), 199-205. https://doi.org/10.14710/anuva.3.2.1 99-205

Lasa. (2017). Manajemen dan standarisasi perpustakaan. Yogyakarta: Majelis Pustaka dan Informasi Muhamadiyah.

Mukhtar, A., \& A. (2019). Iklim organisasi dan kinerja karyawan. SEIKO: Journal of Management $\mathcal{E}$ Business, 2(2), 246255.

https://doi.org/10.37531/sejaman.v2 i2.658

Nugrohoadhi, A. (2015). Pengorganisasian dokumen dalam kegiatan kepustakawanan. Khizanah Al-Hikmah: Jurnal Ilmu Perpustakaan, Informasi, Dan Kearsipan, 3(1), 1-10. https://doi.org/10.24252/kah.v3i1a1

Nuriana, D., \& Amelia, N. (2019). Branding perpustakaan melalui akreditasi: Pentingkah bagi generasi milenial. Tibanndaru: Jurnal Ilmu Perpustakaan Dan Informasi, 3(2), 30-44. Retrieved from

https://journal.uwks.ac.id/index.php /Tibandaru/article/view/764/688

Nurohman, A. (2016). Pengelolaan perpustakaan perguruan tinggi berbasis akreditasi. LIBRARIA: Jurnal Perpustakaan, 4(2), 419-448. https://doi.org/10.21043/libraria.v4i 2.1711

Perpustakaan Nasional Republik Indonesia. (2015). Rencana strategis Perpustakaan Nasional RI tahun 20152019: Keputusan Kepala Perpustakaan Nasional RI Nomor 84 Tahun 2015. Perpustakaan Nasional Republik
Indonesia. Retrieved from https://jdih.perpusnas.go.id/file_per aturan/SK_84_2015_Renstra_Perpusn as_2015_-_2019_publish.pdf

Rahayu, S., Retnaningdyastuti, \& Roshayanti, F. (2019). Pengaruh komunikasi organisasi dan kepuasan kerja terhadap komitmen organisasi guru SD negeri di Kecamatan Bringin Kabupaten Semarang. Jurnal Manajemen Pendidikan (JMP), 8(3), 394-409.

https:// doi.org/10.26877/jmp.v8i3.53 99

Rahman, N., Rahim, S., \& Elfiansyah, H. (2018). Pengaruh pengawasan terhadap efektivitas kerja pegawai kantor PT PLN (Persero) wilayah Sulselbar. Kolaborasi: Jurnal Administrasi Publik, 4(3), 323-337. https:// doi.org/10.26618/kjap.v4i3.1 648

Rijali, A. (2018). Analisis data kualitatif. Alhadharah: Jurnal Ilmu Dakwah, 17(33), 81-95.

https:// doi.org/10.18592/alhadharah .v17i33.2374

Samsuni. (2017). Manajemen sumber daya manusia. Al-Falah: Jurnal Ilmiah Keislaman Dan Kemasyarakatan, 17(1), 113-124.

https:// doi.org/10.47732/alfalahjikk. v17i1.19

Sulistyo-Basuki. (2013). Akreditasi perpustakaan perguruan tinggi. SulistyoBasuki's Blog: Library and Information Science. Retrieved March 25, 2020, from https://sulistyobasuki.wordpress.co $\mathrm{m} / 2013 / 10 / 27 /$ akreditasiperpustakaan-perguruan-tinggi/ 


\section{DAFTAR GAMBAR}

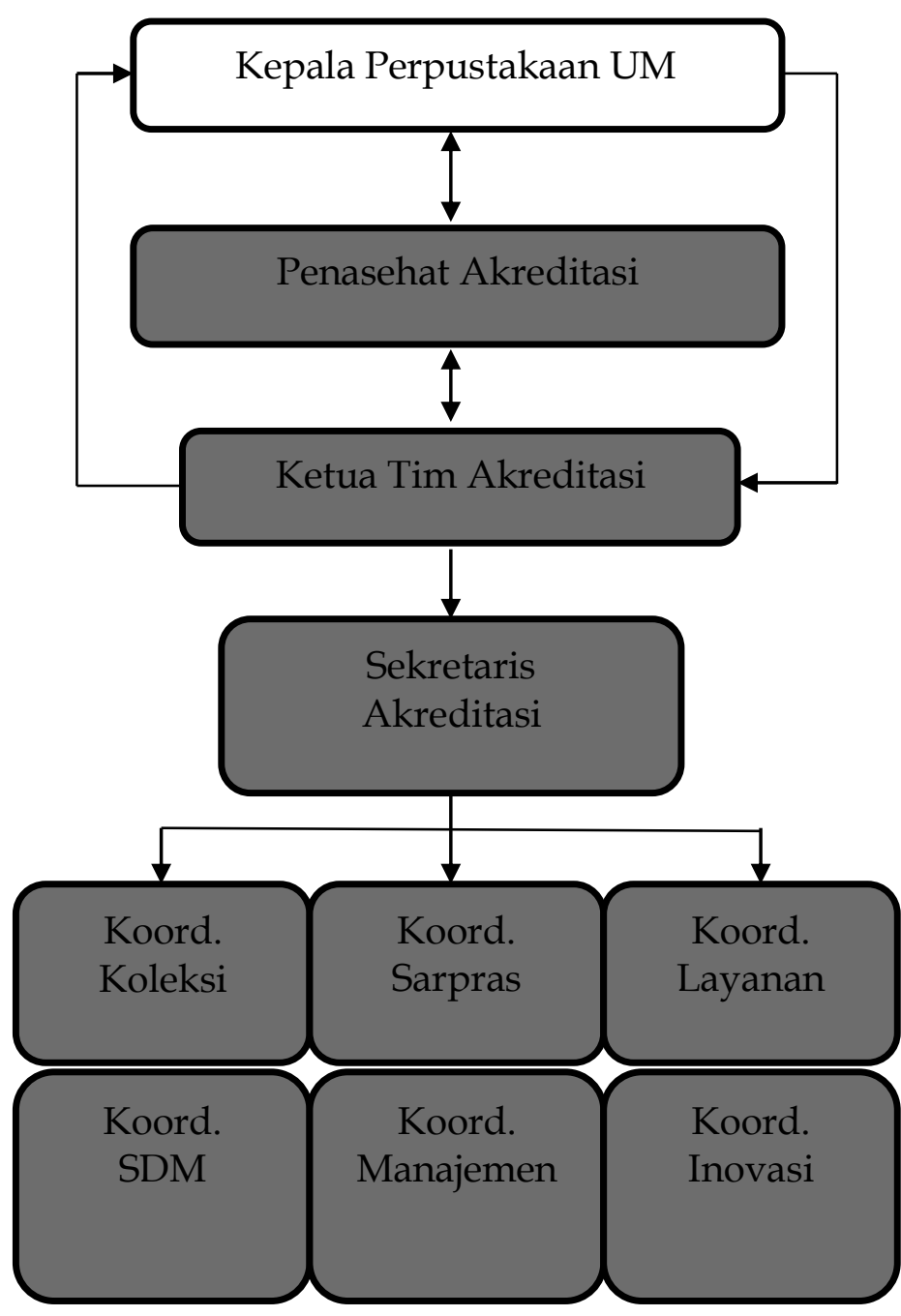

Gambar 1. Struktur tim akreditasi Perpustakaan Universitas Negeri Malang Sumber: Tata Usaha Perpustakaan Universitas Negeri Malang, 2020 